\title{
New Practice in Accommodation Facilities After Covid-19: Safe Tourism Certification Program
}

\section{Altan ÇETIN ${ }^{1}$, Mustafa COŞKUNER ${ }^{2}$}

\begin{abstract}
Covid-19 pandemic, as in many countries in social and economic activities in Turkey has affected in a negative way. One of the sectors that felt the most consequences of this effect is the tourism sector. Crisis management and precautionary policies are implemented in order to prevent possible problems that may arise in the tourism sector as in other sectors. The measures taken by both the state and the society in order to control the pandemic have been named as "New normal" and a new era has begun. The Ministry of Culture and Tourism has implemented the 'Safe Tourism Certification Program', which extends from tourism workers to visitors in Turkey, by taking a series of measures to ensure that all visitors have a holiday within this scope.The purpose of this study is to examine the Safe Tourism Certification Program, which includes the practices taken in the accommodation facilities with the circulars containing the sector-specific measures issued by the Ministry of Culture and Tourism. In the light of the evaluations, at the end of the study, it is revealed that consumers prioritize health and hygiene factors apart from their previous habits in the travel decision and purchasing process and make travel decisions according to the precautions taken.
\end{abstract}

Key Words: Covid-19, Accommodation facilities, Safe tourism, Certification program

JEL Kodu/Code: L83, L30

Referans/Citation: Çetin, A. \& Coşkuner, M. (2021). New practice in accommodation facilities after covid-19: Safe tourism certification program, Journal of Hospitality and Tourism Issues, Vol. 3, No.1, 16-22.

\section{INTRODUCTION}

There may be many reasons adversely affecting tourism sector in the World. One of them is epidemics (pandemics) that spread in more than one country or continent in the world and show their effect in a very wide area. An infectious disease, seen as an epidemic in a region, is transported to other regions and countries by travel. Therefore, the disease that occurs in a part of the world poses a potential danger to the country we live in. A traveler can carry a disease from the region he lives in to another region or cause an infectious disease that he has taken from the country he travels to spread within his own region (Özdemir, 2005: 392). The Covid-19 outbreak has also greatly affected the service sector, where people have high interactions with each other. In particular, the tourism sector is one of the sectors directly affected by the epidemic due to measures such as social distance, quarantine, curfew.

Epidemics have a negative impact on the number and income of tourists in the tourism sector. For example, many tourism-based sectors such as air transport, land transport, entertainment and hotel management have been severely damaged (Demir, 2020: 7). This situation has negative consequences for the tourism industry, such as changing travel plans, canceling reservations and closing the borders to

\footnotetext{
${ }^{1}$ Phd, Anadolu University, altanctn26@gmail.com Orcid ID: 000-0002-4271-4760

${ }^{2}$ Phd, Anadolu University, mustafacoskuner03@gmail.com, Orcid ID: 0000-0003-3032-1836
} 
the citizens of the countries where the epidemic is seen (Acar, 2020: 8). In this context, governments and local administrators have determined measures including hygiene and behavioral rules to be followed for the epidemic in order to ensure the continuity of normal life, along with practices that will minimize the contagiousness of the virus and the contact of people for the continuity of the sector. Efforts have been made to separate tourism from this situation with the least damage. The mandatory rules regarding accommodation businesses, food and beverage businesses and tourist guiding activities have been announced separately by the Ministry of Culture and Tourism (Republic of Turkey, Ministry of Culture and Tourism, 2021). In the following process, the number of Covid-19 cases was brought under control with the measures taken, and travel restrictions began to be lifted with the decisions of the countries. The last report of the World Tourism Organization on Covid-19 also supports this situation. According to the report, 152 destinations have eased the measures regarding travel restrictions related to Covid-19 (UNWTO, 2021). Accommodation businesses, which temporarily terminated their activities due to the decrease and restrictions in occupancy rates, started to operate again after the announcement of the measures and rules (Kılıç et al., 2020: 556). It is envisaged that travel restrictions, which have been mitigated/eliminated by taking the necessary measures, will revive national and international tourism movements in the long term, albeit in a limited way. In this context, the aim of the study is to introduce the "Safe Tourism Certificate", which includes the measures taken in accommodation facilities published by the ministry, and to examine the specified practices and measures in terms of the tourism sector.

\section{EVALUATION OF THE TOURISM SECTOR AFTER COVID-19}

One of the reasons why pandemic is associated with tourism; are international travels that are extremely effective in the spread of the disease and the expansion of its area of influence. When the recent scientific studies on the Covid-19 pandemic (Acar, 2020; Wilson \& Chen, 2020) are examined, it is seen that the international travels of people carrying the virus play an important role in the spread of the pandemic around the world. Turkey's tourism sector has been one of the sectors most exposed to performance loss during Covid -19 outbreak affecting the whole World. In the period of March 2020, while the entries and exits in many countries of the world were brought under control, restrictions were imposed on travel, especially international flights.

It can be said that the airline and accommodation sector, which is in the travel and tourism sector, is one of the sectors that have been most affected by the Covid-19 outbreak (Aydın \& Doğan, 2020: 98). Many facilities have had to temporarily or permanently close their facilities, with a significant decrease in workforce. According to the international data and analyzes prepared by the Turkish Hoteliers Association (TÜROB) and the hotel occupancy data made by STR Global in cooperation with European destinations, the average occupancy rate in September 2020 decreased by $51.7 \%$ to $38.9 \%$. In our country, the negative effects of the pandemic were first seen in the airline and accommodation sectors. In January-October 2020, covering the first ten months between the number of foreign visitors arriving in Turkey, there has been a decrease of 72.5 percent compared to the same period of 2019. Turkey's overall occupancy rate decreased by 47.8 percent in the period covering January-September 2020 compared to the same period of the previous year, and the average occupancy rate in the nine-month period was reported as 35.4 percent. Most accommodation occupancy rates held in Istanbul and Antalya in Turkey has not reached the expected level. In the first 9 months in Istanbul, the occupancy rate decreased by 50.8 percent to 36.9 percent. In Antalya, the occupancy rate in the first 8 months decreased by $41 \%$ compared to the same period of the previous year and became $39.8 \%$. However, in addition to 
these developments, with the gradual opening of airline transportation as of June 2020, a partial dynamism started to be experienced in the accommodation sector.

During and after the pandemic process in which hygiene came to the fore, changes occurred in the travel expectations of consumers. While "affordable price" was always the first choice in holiday choices in previous years, with the pandemic, hygiene and safety replaced affordable prices. Willingness to travel increases as long as security can be guaranteed. After considering how the situation in the Covid-19 epidemic develops in the region where they will go on vacation, they plan to make a holiday and reservation. Providing clear information and assurance that destinations and facilities do not contain Covid-19 and that all necessary precautions are taken has gained great importance in promoting hotel reservations (TÜRSAB, 2020).

\section{SAFE TOURISM CERTIFICATION PROGRAM}

As a result of the measures taken to prevent the spread of the Covid-19 epidemic, which was included in the scope of "Pandemic" by the World Health Organization (WHO), the rate of spread and transmission of the virus decreased, there was a decrease in the fight against epidemic diseases and in parallel with the positive developments, the rate of increase in cases decreased. In the Presidential Cabinet meeting on 28.05.2020, in line with the recommendations of the Scientific Committee, some of the restrictions imposed in this process could be lifted and the measures that could be taken were evaluated. In this context, legislative provisions permitting the activities of hotels, thermal/spa hotels, motels, apart hotels, pensions, guesthouses/camps belonging to public institutions and organizations and all kinds of accommodation facilities and measures regarding occupational health and safety were determined. In addition, measures should be taken and its continuity should be ensured (Ankara Valiliği, 2021)

The most comprehensive regulations were prepared with the aim of protecting the health of tourists and employees. it is called "Safe Tourism Certification Program" and prepared by the Ministry of Culture and Tourism. The "Safe Tourism Certification Program", one of the first and most comprehensive applications in the world, was prepared under the leadership of the Ministry of Culture and Tourism, with the contributions of the Ministries of Health, Transport, Interior and Foreign Affairs and in cooperation with all sector stakeholders. In order to have this certificate, it is required to have a minimum level of hygiene pursuant to some mandatory applications. As a result of inspections in the field of hygiene and health, based on 166 different criteria by 18 different international assessment organizations, facilities that meet the requirements are entitled to receive a "Safe Tourism Certificate". This app holidays from access to all Turkish citizens and foreign visitors to Turkey will be spent in accommodation, facilities from employees to the passengers are recommended a series of measures to be taken in a wide range of their own health status. Within the scope of COVID-19, in order to enable a healthy and safe tourism under extraordinary pandemic conditions and to ensure the high level of reliability of the measures taken; Safe Tourism Certificate, which documents the fulfillment of highlevel health and hygiene conditions in accommodation facilities implemented by international certification bodies and which aims to ensure its continuity through monthly inspections, has been made obligatory for all accommodation facilities with a capacity of 50 rooms or more, with or without a certificate from the Ministry (Afyonkarahisar İl Kültür ve Turizm Müdürlügü, 2021). Organizations are also the competencies by Turkey Accreditation Agency it is between the notified bodies. Facilities that receive the certificate by complying with 166 criteria are announced on the official website of the Ministry of Culture and Tourism. The Safe Tourism Certificate logo is displayed on the visible points of the facilities receiving the certificate and customers can access all the inspection information about 
the facility thanks to the QR code on the certificate (TGA, 2021). Within this framework, a safer service has started to be provided in the facilities holding the Safe Tourism Certificate.

Some important criteria that accommodation facilities must meet for Safe Tourism Certificate (ETS, 2021) are as follows:

- Having personnel in charge to fulfill the contamination precautions and hygiene standards within the facility,

- In order to prevent the accumulation in the units at the entrances of the facility, warning signs indicating the social distance by marking the places and considering the people staying in the same room as a group in accordance with the social distance rules,

- Placement of alcohol-based hand sanitizer or disinfectant unit approved by the Ministry of Health in common areas within the facility,

- Hanging printable wall diagrams in staff areas and general areas belonging to Covid-19 and hygiene practices and translating these wall diagrams into at least 3 languages,

- Providing written information to the guests at the reception of the facility about the measures and practices taken against Covid-19 regarding hygiene and the rules that the guests must obey,

- Keeping a mask ready at the entrance of the facility, along with protective clothing and equipment, if requested,

- Natural ventilation of the spaces, when necessary, by changing the ventilation filters periodically,

- Ensuring temperature measurements with a thermal sensor during entry and exit of the employees in the facility, and simultaneously recording and monitoring biometric facial recognitions; Body temperature checks and recording with facial images of the guests with thermal cameras or thermometers with non-contact thermal sensors,

- Leaving the rooms empty for 12 hours after use and quarantining guest rooms diagnosed with Covid-19 for 72 hours.

Tourism businesses who have this certification, promotion and by promising that they fulfill the certification criteria in their marketing activities, they try to prevent a possible "trust" problem in tourists (Türker \& Ertürk, 2020: 99). The number of accommodation facilities participating in the Safe Tourism Certification Program implemented under the leadership of the Ministry of Culture and Tourism and continuation of holding certificate has been increasing day by day. Turkey Tourism Promotion and Development Agency (TGA) 's website located at number 4222 of date 08.02.2021 ministry facility certified according to current data, 2011 registered hotels in Turkey was eligible to receive this document. The certification process of 15 facilities is ongoing (TGA, 2021).

With the approach of the end of tourism season has begun to March 13, 2021 date of Culture and Ministry of Health with the Ministry of Tourism in Turkey which was implemented on behalf of the interruption of tourist services are open with Safe Tourism Certification work to be taken to the accommodations of the vaccination program. In this direction, a data entry system specific to businesses has been created in this system, which has been integrated with the Safe Tourism Certificate program. The vaccination system will primarily start with the personnel working in outdoor facilities. The process of including the staff in the vaccination program on time by the facility officials should be followed carefully and the staff should be informed about this issue. In this process, it is important that the staff, whose turn is to be vaccinated, take their appointment on time via the e-pulse system (TGA, 2021). In this context, it is expected that the Safe Tourism Certification Program in Turkey will provide an advantage in competition with other countries, and the tourism personnel vaccination systems will give confidence to the tourists who will visit the country. 
In addition to practices such as the safe tourism certificate applied in our country, global measures for "new normal" and Global Security Stamp to Recognize Safe Travel Protocols have emerged in the world. The Safe Travels Stamp has been created by the World Travel \& Tourism Council for travelers to recognize destinations and businesses around the world that have adopted the SafeTravels in accordance with the health and hygiene global standard protocols. This specially designed stamp will allow travelers to recognize governments and companies around the world that have adopted SafeTravels health and hygiene standardized protocols, so consumers can experience 'Safe Travels'. All businesses related to tourism such as hotels, restaurants, airlines, cruise lines, tour operators, tourist attractions, car rental, transportation and airports will be able to use this stamp, which includes the health and hygiene protocols implemented by WTTC (WTTC, 2021).

\section{CONCLUSION AND SUGGESTIONS}

Within the scope of the measures to prevent the spread of the pandemic (COVID-19) epidemic, the controlled normalization process has been launched by the World Health Organization. After the successful fight against the epidemic, it is envisaged that travel and tourism activities will be restarted in a healthy process. Like many other sectors, the tourism sector, which is adversely affected by the epidemic, also has an effort to minimize the damage with the measures taken. For this reason, the service that accommodation facilities will provide by establishing safe areas is of vital importance for the tourism sector.

It is a predictable behavior that people who need a holiday due to the anxiety experienced because of the pandemic will first question the measures for the facility where they will spend their holiday . During the pandemic process, personal safety and health is a new consumer expectation that is perceived as a basic need besides the benefit-price relationship and ease of purchase. Businesses must respond to customers' new safety and hygiene demands to express their commitment to customer health and safety by understanding them. Thanks to these measures taken by the state for both accommodation facilities and other businesses against the epidemic, the hygiene rules to be followed were determined and their activities were initiated. In the New Normal Period, most of the businesses, including the hotels closed within the scope of the measures, were opened and continue to open.

During the pandemic process, it is seen that the most comprehensive applications in the tourism sector are in the field of accommodation. Some regulations regarding the provision of services in accommodation facilities, such as online entry-exit records, technological systems such as the use of contactless transactions on room door cards, full implementation of daily health measures, sterilized kitchen applications and a la carte service in restaurants are perceived as practices that can reduce the concerns of consumers about Covid-19 contamination. The full implementation of the measures taken by the accommodation businesses during holiday purchasing process may significantly reduce the anxiety of people, even if they are not completely eliminated (Demir et al., 2020: 89). There are some studies in the literature that support this view. According to the findings obtained in these studies (Chebli, Said, 2020; Kılıç et al., 2020; Kourgiantakis, 2020); tourists will pay particular attention to hygiene and cleanliness during their post-epidemic holidays, and the safe tourism certificate given to accommodation facilities is also an important criterion in their holiday choices. The results have emerged that tourists are ready to pay more for accommodation in facilities with this certificate. This situation clearly reveals the importance of confidence in the certification program for the consumer.

Post-epidemic tourism experiences are predicted to be sustainable with more cautious tourists. Nowadays, where hygiene is important, tourist expectations will also be reshaped and the period when hygiene-themed business is at the forefront will prevail. (Mostafanezhad, 2020: 5). In addition, it is 
expected that conducting hygiene-themed activities in accommodation facilities will be extremely important in terms of gaining the trust of visitors and providing a competitive advantage. In addition to accommodation facilities, airline companies have also taken some measures (contactless check-in processes, social distance application, extra cleaning measures, hygiene kits) and developed innovations in order to ensure healthy and safe travel for their passengers during the pandemic process. In this context, Turkish Airlines was deemed worthy of Diamond status, which is the highest level in the health safety assessment of APEX (Airline Passenger Experience Association), with its safe travel experience and hygiene measures taken during the epidemic period (Turkish Airlines, 2021). Such practices create confidence in international transportation for passengers who are worried about travelling in the pandemic period.

In order for the accommodation sector to successfully manage the pandemic, it is vital for businesses to know the new demands and expectations of consumers. It is deemed necessary by consumers to know what the points of attention of accommodation facilities regarding the pandemic are, to show sensitivity in these issues and to make up for their deficiencies, in order for the facilities to exit this process with the least damage. Therefore, this study on the Safe Tourism Certification Program is informative and descriptive about the measures taken by accommodation facilities and the issues to be considered, and it is thought that it will contribute to the tourism literature during and after the pandemic process.

\section{REFERENCES}

Acar, Y. (2020). Yeni Koronavirüs (Covid-19) Salgını ve turizm faaliyetlerine etkisi [The novel coronavirus (Covid-19) outbreak and impact on tourism activities]. Güncel Turizm Araştırmaları Dergisi. 4(1), 7-21.

Afyonkarahisar İl Kültür ve Turizm Müdürlüğü (2020). Haber arşivi, Retrieved March 2021, from https://afyon.ktb.gov.tr/TR-269855/guvenli-turizm-sertifikasi-alan--turizm-ve-belediye-isl-.html

Ankara Valiliği (2020). Retrieved March 032021 from http://ankara.gov.tr/konaklama-tesislerindeuygulanacak-standartlar-ve-tedbirlerle-ilgili-uhk-kararlarina-iliskin-basin-aciklamasi

Aydın, B. \& Doğan, M. (2020). Yeni koronavirüs (COVID-19) pandemisinin turistik tüketici davranışları ve Türkiye turizmi üzerindeki etkilerinin değerlendirilmesi [Evaluation of effects of the covid-19 pandemic on touristic consumption behavior and tourism in Turkey]. Pazarlama Teorisi ve Uygulamalarl Dergisi, 6(1), 93-115.

Chebli, A. \& Said, F. B. (2020). the impact of covid-19 on tourist consumption behaviour: A perspective article. Journal of Tourism Management Research, 7(2), 196-207.

Demir, İ. (2020). Kovid-19 (Koronavirüs) salgınının ekonomik etkileri [Economic effects of the Covid19 (Coronavirus) outbreak]. Institute for International Relations and Strategic Research (IIRSR), 12(1), 1-30.

Demir, M., Demir, Ş. Ş., Ergen, F. D. \& Dalgıç, A. (2021). Covid-19 sürecinde tüketicilerin otel seçimini etkileyen faktörler [The factors affecting hotel choice of consumers during the Covid-19 process]. International Journal of Social Sciences and Education Research, 7 (1), 82-94.

ETS (2021), Güvenli turizm sertifikası hangi şartları yerine getiren otellere verilir? Retrieved March 03 2021, from https://etstur.com/letsgo/guvenli-turizm-sertifikasi-hangi-sartlari-yerine-getiren-otellereverilir/ 
Çetin \& Coşkuner (2021), Johti, 3(1), 16-22

Kılıç, B., Aslan, H. \& Gövce, M. (2020). Covid-19 sonrası turistik tüketim tutumu [Tourist's consumption attitude after Covid-19]. Gaziantep University Journal of Social Sciences, 2020 Special Issue, 554-570.

Kourgiantakis, M., Apostolakis, A. \& Dimou, I. (2020). Covid-19 and holiday intentions: The case of Crete, Greece. Anatolia, 1-4.

Metin, S. (2020). Turizm ve kovid-19 [Tourism and Covid-19]. (1.basım) Ankara. İksad Yayınevi.

Mostafanezhad, M. (2020): Covid-19 is an unnatural disaster: Hope in revelatory moments of crisis, Tourism Geographies, 22(3), 1-7.

Özdemir, M. (2005). Yurtdışından girişlerde dezenfeksiyon uygulamaları ve yapılan yanlışlar [Disinfection practices and mistakes made at entries from abroad]. 4. Ulusal Sterilizasyon Dezenfeksiyon Kongresi, Samsun. 392-396.

TGA, (2021). Sertifikalar, Retrieved March 032021 from https://tga.gov.tr/searchhotel/?certificateType $=4$

Turkish Airlines (2021). Basin bültenleri Retrieved March 24, from https://www.turkishairlines.com/trit/haberler-ve-basin-bultenleri/? $p=1$

Türker, G. Ö. \& Ertürk, N. (2020). Covid-19 effects on the hospitality industry: an assessment from the perspective of managers, Turizm Ekonomi ve İşletme Araştırmaları Dergisi, 2(2), 89-101.

TÜRSAB (2020). Covid 19 sürecinde Türkiye ve Dünya değerlendirmesi, Retrieved March 03, 2021 from https://tursab.org.tr/apps//Files/Content/6ad52b35-1dd2-41c2-9f1c-c24cc19e7a63.pdf

UNWTO (2021), Retrieved March 042021 from https://unwto.org/news/70-of-destinations-have-liftedtravel-restrictions-but-global-gap-emerging

Wilson, M. E. \& Chen, L. H. (2020). Travellers give wings to novel coronavirus (2019-nCoV). Journal of Travel Medicine, 1-3.

WTTC (2021). Retrieved May 292021 from https://wttc.org/COVID-19/Safe-Travels-GlobalProtocols-Stamp.

Yazar(lar) Hakkında/About Author(s)

Altan ÇETíN/ altanctn26@gmail.com

Altan Çetin is a PhD student in the department of Tourism Management at Anadolu University. He received his master's degree in the department of tourism management at Anadolu University. Çetin, who has studies on destination image and he is currently studying cultural tourist and tourist experience. He continues his doctorare education in tourism management at Anadolu University.

\section{Mustafa Coskuner/mustafacoskuner03@gmail.com}

Mustafa Coskuner completed his primary and secondary education in Aksaray. His undergrate education is on English teaching. He received his master's degree in the departmen of travel management and tourism guidance from Selcuk University. Coskuner who has studies on touristic product and destination marketing, continues his $\mathrm{PhD}$ in the tourism managament at Anadolu University. 